OPEN ACCESS

Edited by:

Fatima Baltazar,

University of Minho, Portugal

Reviewed by:

Yaron Sitrit,

Ben-Gurion University of the

Negev, Israe

Duraipandiyan Veeramuthu,

King Saud University, Saudi Arabia

*Correspondence:

Wamidh H. Talib

w_talib@asu.edu.jo

Specialty section:

This article was submitted to Clinical Nutrition

a section of the journal

Frontiers in Nutrition

Received: 13 June 2019

Accepted: 17 March 2020

Published: 08 April 2020

Citation:

Al Obaydi MF, Hamed WM, Al Kury LT and Talib WH (2020) Terfezia boudieri:

A Desert Truffle With Anticancer and Immunomodulatory Activities.

Front. Nutr. 7:38.

doi: 10.3389/fnut.2020.00038

\section{Terfezia boudieri: A Desert Truffle With Anticancer and Immunomodulatory Activities}

\author{
Maha Farid Al Obaydi ${ }^{1}$, Wafaa M. Hamed ${ }^{2}$, Lina T. Al Kury ${ }^{3}$ and Wamidh H. Talib ${ }^{1 *}$ \\ ${ }^{1}$ Department of Clinical Pharmacy and Therapeutic, Applied Science Private University, Amman, Jordan, ${ }^{2}$ Pharmacy \\ Department, AINoor University College, Mosul, Iraq, ${ }^{3}$ Department of Health Sciences, College of Natural and Health \\ Sciences, Zayed University, Abu Dhabi, United Arab Emirates
}

Desert truffles have high nutritional value and grow wild in the Mediterranean basin and Western Asia. Although, many studies were performed to evaluate truffles nutritious values and phytochemical composition, studies are limited to evaluate their anticancer and/ or immunomodulatory effects. Our study was conducted to evaluate the anticancer and immunomodulatory effects of Terfezia boudieri (desert truffle). Different solvent extracts were prepared from the truffle and MTT assay was used to measure their anticancer activity against cancer cell lines (T47D, MCF-7, MDA-MB231, HCT-116, and Hela). Total phenolic content in each extract was determined by using Folin-Ciocalteu reagent and qualitative phytochemical screening was performed using standard methods. The degree of apoptosis induction (using caspase 3 assay) and vascular endothelial growth factor expression were detected using standard kits. Also, ELISA was used to measure levels of IFN- $\gamma, \mathrm{IL}-2, \mathrm{IL}-4$, and IL-10 secreted by splenocytes after treatment with the extracts. The effect of the extracts on splenocytes proliferation was measured using MTT assay. Macrophage function was evaluated using nitro blue tetrazolium assay and pinocytosis function was evaluated using neutral red method. Terpenoids, phytosterols, and carbohydrates were present in all the solvent extracts, while tannins, alkaloids and flavonoids were detected only in aqueous/methanol and aqueous extracts. The highest total phenolic content was observed in aqueous and aqueous methanol extracts. The growth of cancer cell lines was inhibited by T. boudieri extracts in a dose dependent manner. $\mathrm{N}$-hexane extract was the most potent against most cell lines. Aqueous/methanol extract showed high apoptosis induction and angiogenesis suppression effects. An increase in TH1 cytokines (IFN- $\gamma$, IL-2) level and a decrease in TH2 cytokine (IL-4) level were evident after lymphocytes stimulation by aqueous/methanol, n-hexane and ethyl acetate extracts of $T$. boudieri. Ethyl acetate extract of $T$. boudieri were the most potent extracts to stimulate lymphocytes proliferation while all other extracts showed moderate stimulation. Aqueous/methanol extract was the most active extract to stimulate phagocytosis. Ethyl acetate extract was the most active extract to stimulate pinocytosis. The use of $T$. boudieri provides variable health benefits. N-hexane, ethyl acetate, and aqueous/methanol extracts exhibited anticancer activities and are potent stimulators of innate and acquired immunity. Further testing is needed to identify the biologically active compounds and detect them quantitatively using GC-MS analysis.

Keywords: truffles, fungi, anticancer, functional food, immunomodulatory 


\section{INTRODUCTION}

Cancer is a global health problem and number of cancer patients is in continuous rise (1). Approximately, and according to World Health Organization (WHO), there were 14.1 million new cancer cases and expected to rise to 22 million within the next two decades. Additional statistics showed that $70 \%$ of deaths from cancer occur in low and middle income countries (2). Therefore, cancer became a heavy problem worldwide (3). The economic impact of cancer is significant and is increasing. The total annual economic cost of cancer treatment in 2010 was estimated at approximately US $\$ 1.16$ trillion (4).

Diet is one of the most important factors for the formation and prevention of cancer, the link between them is just as mysterious as the disease itself (5). Researches have pointed to certain nutrients and foods that may help contribute or, conversely, prevent certain types of cancer (6). High intakes of fruit and vegetables with high antioxidants and fibers tend to reduce the risk of cancer at several sites. Evidences have been derived the relationship between consumption of vegetables and fruits and the risk of several common cancers (7). Total intake of calories seems to have a strong positive influence on causing cancer, and the increasing in breast, colon, and prostate cancer incidence is associated with consumption of fat-rich food (8).

The use of conventional anticancer therapies (chemotherapy and radiation) is associated with serious side effects (9). These side effects encourage scientists exploring alternative cancer therapies to enhance the efficiency of current therapies and reduce toxicity. An attractive source for these therapies was the natural products (10). Among them were the edible medicinal fungi which produce medically significant metabolites or can be induced to produce such metabolites using biotechnology (11). These fungi may inhibit cancer cell by augmenting the function of the immune system (12).

About 82,000 fungal species were discovered and yet to be (13). Macrofungi can be classified into two types: epigeous (mushrooms) and hypogeous (truffles) (14). Modern medicine rediscovered ancient super foods, as a growing evidence that mushrooms (such as White button, Shiitake, Maitake, portabella, Reishi, Turkey Tail) are among the potentially positive foods for cancer fighting and prevention (15). Previous research on Terfezia boudieri reported a remarkable antibacterial, antioxidant, and radical scavenging activities of flavonoids rich extract of this truffle $(16,17)$.

In spite of the fact that recent truffles research emphasis on the chemical properties (nutritional and aromatic profile) and their potential biological activities, further scientific studies need to pay greater attention to the value added to truffles.

This study was executed to investigate the benefits of Terfezia boudieri extracts as a source of immunomodulatory and anticancer agents.

\section{MATERIALS AND METHODS}

\section{Cell Lines and Cell Culturing Condition}

Six cell lines were used to investigate the anticancer effect of T. boudieri extracts. The cells were cultured in complete medium and incubated at $37^{\circ} \mathrm{C}$ in $5 \% \mathrm{CO}_{2}, 95 \%$ humidity incubator. Two human epithelial breast cancer cell lines (T47D and MCF-7), human breast adenocarcinoma cell line (MDA-MB-231), human colon carcinoma cell line (HCT-116), and human epitheloid cervix carcinoma cell line (Hela) were used in this study. T47D and MCF-7 cell lines were cultured in complete RPMI 1640 medium. MDA-MB231, HCT-116, and Hela cell lines were cultured in complete DMEM medium with high glucose. Kidney epithelial cells from African green monkey (Vero) were used as normal control and cultured in complete DMEM medium. All culture media were supplemented with $1 \%$ L-glutamine, $10 \%$ fetal bovine serum, $1 \%$ penicillin-streptomycin, and $0.1 \%$ gentamycin solution.

\section{Truffles Collection and Extracts Preparation}

Truffles (T. boudieri) were purchased from Jordanian market, and identified by Mr. Anas AbuYahya (monitoring and evaluation specialist/ flora researcher, in the Royal Society for the Conservation of Nature, Amman- Jordan). Fresh truffles were cleaned well (by brush followed by wet towel), sliced (to the thickness of about $1-3 \mathrm{~mm}$ ), dried, powdered and kept in dry and dark place. Different extracts using solvents of different polarities were prepared from $250 \mathrm{~g}$ of the powdered truffle material. Aqueous/methanol (80:20\%) extract was prepared by macerating the dried powder $(250 \mathrm{~g})$ at room temperature for 3 days. Then the extract was filtered and the supernatant was concentrated using rotary evaporator. Complete drying of the extract was achieved using lyophilizer, and then the extract was kept at $-20^{\circ} \mathrm{C}$ until used. Water, n-hexane and ethyl acetate extracts were prepared by dissolving of aqueous/methanol extract $(1.5 \mathrm{~g})$ in water, then fractionating it using $\mathrm{n}$-hexane, followed by ethyl acetate. Both fractions were concentrated using rotary evaporator. The remaining water fraction was dried completely and all extracts was stored at $-20^{\circ} \mathrm{C}$ until used.

\section{Phytochemical Screening}

Phytochemical examinations were carried out for all T. boudieri extracts. A qualitative chemical screening for identification of various classes of active chemical constituents such as saponins, tannins, phytosterols, terpenoids, alkaloids, flavonoids, anthraquinones, and carbohydrates were performed. Detection of the extracted compounds was done according to the standard methods described by Trease and Evans (18).

\section{Total Phenolic Content (TPC) by Folin-Ciocalteu Method}

The amount of TPC in T. boudieri extracts was determined according to the F-C procedure described by Akyüz (17). A stock solution of $25 \mathrm{mg} / \mathrm{ml}$ of each extract was prepared. Five different dilutions were further made from each stock as 20, 15, 10, 5, 2.5 $\mathrm{mg} / \mathrm{ml}$. Briefly, $12.5 \mu \mathrm{l}$ of each dilution was mixed with $250 \mu \mathrm{l}$ of $2 \%$ sodium carbonate solution in 96 -well microplate in duplicate. They were allowed to react for $5 \mathrm{~min}$ at room temperature (RT). Then, $12.5 \mu \mathrm{l}$ of $50 \% \mathrm{~F}-\mathrm{C}$ reagent was added and allowed to stand again for $30 \mathrm{~min}$ at RT. The absorbance of reaction mixture was read using a plate reader at $630 \mathrm{~nm}$. A standard 
curve was obtained using gallic acid standard solution at various concentrations ranging from 0.1 to $1.0 \mathrm{mg} / \mathrm{ml}$ in distilled water. Total phenolic content $(\mathrm{mg} / \mathrm{ml})$ of each extract was obtained the standard curve of gallic acid. Data are expressed as equivalent of gallic acid (mg) for each milliliter of each extract (19).

\section{ANTIPROLIFERATIVE ASSAY}

Cells (from different cell lines) were dispensed (100 $\mu \mathrm{l} /$ well) into 96-well tissue culture plates (flat bottom) at an optimized concentration of 15,000 cells/well in complete tissue culture medium. After $24 \mathrm{~h}$, the media in each well were completely removed and the attached cells were treated in triplicates with decreasing concentrations of different extracts (initially dissolved in DMSO) of T. boudieri (25-0.78 $\mathrm{mg} / \mathrm{ml}$. Plates were incubated for $48 \mathrm{~h}$, and then cell viability was measured by using MTT [3-(4,5-Dimethylthiazol-2-yl)-2,5-diphenyltetrazolium bromide] assay kit (Sigma, USA) assay as previously described (20). Percentage survival was calculated by comparing the absorbance of treated cells to that of untreated cells (tissue culture media + $0.1 \%$ DMSO). The concentration at which there was $50 \%$ of cell death $\left(\mathrm{IC}_{50}\right)$ was calculated using non-linear regression in SPSS.

\section{Determination of VEGF Expression in T47D Cells}

T47D cells were dispensed into four separated tissue culture flasks at a concentration of 150,000 cells/ml of complete tissue culture medium. After $24 \mathrm{~h}$, the media in each flask was completely removed and the attached cells were subjected to one of the following treatments: aqueous/methanol extract at a concentration of $12.5 \mathrm{mg} / \mathrm{ml}, 250 \mathrm{nM}$ of doxorubicin, and a negative control (tissue culture media $+0.1 \%$ DMSO). Cells were incubated for $48 \mathrm{~h}$, after that the media of each flask were transferred into sterile tubes and VEGF levels were measured using VEGF ELISA kit (Sigma-Aldrich, St. Louis, MO, USA) as previously described (21). A standard curve was obtained using mouse VEGF at various concentrations. The concentration of VEGF for each treatment was obtained using VEGF standard curve. Data are expressed as equivalent of VEGF (pg/ml) for each milliliter of the extract.

\section{Apoptosis Detection in T47D Cells}

T47D cells were dispensed into four separated tissue culture flasks at a concentration of 150,000 cells/ml of complete tissue culture medium. After $24 \mathrm{~h}$, the media in each flask was removed and the attached cells were treated with one of the following treatments: aqueous/methanol extract at a concentration of 25 $\mathrm{mg} / \mathrm{ml}, 250 \mathrm{nM}$ of doxorubicin hydrochloride, and a negative control. Cells were incubated for $48 \mathrm{~h}$ with different treatments, after that the media of each flask were removed and the attached cells were harvested. Caspase-3 activity was measured using kit instructions (Sigma-Aldrich, St. Louis, MO, USA). Fold-increase in Caspase 3 activity was determined by comparing extracts results with the level of the negative control. Detailed and step by step procedure was conducted as described previously (22).

\section{Mice}

$\mathrm{Balb} / \mathrm{C}$ female mice were used in this study. Mice were 46 weeks old with average body weight of 21-25 g/mouse. All animal procedures were studied and approved by the Research and Ethical Committee of Applied Science University (Approval Number: 2017-PHA-9). Separate cages with bedding of wood shaving were used to house mice. The environmental conditions of the animal house were stable temperature at $25^{\circ} \mathrm{C}, 50-60 \%$ humidity, continuous air ventilation, and alternating light/dark cycles of $12 \mathrm{~h}$.

\section{Preparation of Murine Splenocytes}

Balb/C mouse was sacrificed and the spleen was removed aseptically. The cells of the spleen (splenocytes) were freed by passing spleen tissue through a mesh of a tissue grinder. A suspension of splenocytes was prepared in RPMI-1640. The cell suspension was washed three times using RPMI-1640 and then re-suspended in $5 \mathrm{ml}$ red blood cells lysis buffer $(1 \mathrm{~mol} / \mathrm{L} \mathrm{NH} 4 \mathrm{Cl})$. After $10 \mathrm{~min}$ the cells were again centrifuged and re-suspended in RPMI-1640 media. Splenocytes were washed and cell viability was detected using trypane blue assay. Different densities of cell suspension were counted and used in other assays.

\section{Determination of Cytokines Levels in Activated Lymphocytes}

Levels of IFN- $\gamma$, IL-2, IL-4, and IL-10 were measured for splenocytes cultured for $48 \mathrm{~h}$ with different extracts of T. boudieri using mouse TH1/TH2 ELISA kit (affymetrix ebioscience, Canada). Briefly, splenocytes suspension were made $\left(2 \times 10^{6}\right.$ cells/ml) in complete RPMI-1640 and were seeded into 96-well culture plate, $100 \mu \mathrm{l}$ of different truffle extracts $(25 \mathrm{mg} / \mathrm{ml}$ in RPMI-1640) were added (triplicate), and the plate was incubated for $48 \mathrm{~h} \mathrm{CO} \mathrm{CO}_{2}$ incubator. After incubation, culture supernatants were collected to estimate the concentrations of IFN- $\gamma$, IL-2, IL4, and IL-10 using standard kit as previously described (23). A standard curve was prepared using known concentrations of each cytokine. The absorbance values obtained for each treatment were converted into concentration $(\mathrm{pg} / \mathrm{ml}$ ) using standard curve.

\section{Lymphocytes Proliferation Assay}

This assay was performed using MTT [3-(4, 5-Dimethylthiazol2-yl)-2, 5-diphenyltetrazolium bromide] assay kit (Sigma, USA) according to the manufacturer's instructions. Briefly, splenocytes suspension were made $\left(2 \times 10^{6}\right.$ cell $\left./ \mathrm{ml}\right)$ in complete RPMI-1640 and were seeded into 96-well culture plate in the presence of $5 \mu \mathrm{g} / \mathrm{ml}$ Con A or $4 \mu \mathrm{g} / \mathrm{ml}$ LPS. To this, $100 \mu \mathrm{l}$ of increasing concentrations (5-25 mg/mL in RPMI-1640) of T. boudieri extracts were added (triplicate). The plate was incubated for $48 \mathrm{~h}$ under $5 \% \mathrm{CO}_{2}$ and humidified atmosphere of $95 \%$ air at $37^{\circ} \mathrm{C}$ temperature. After the incubation, $10 \mu \mathrm{l}$ MTT ( $5 \mathrm{mg} / \mathrm{ml})$ solution was added to each well. The plate was wrapped with aluminum foil to avoid exposure to light and incubated for $4 \mathrm{~h}$. Then 100 $\mu l$ DMSO was added to each well to dissolve the formazan particles and the absorbance was measured at $550 \mathrm{~nm}$ using ELISA microplate reader. Results were expressed as a percentage of proliferation (\%) compared to the negative control cells (24). 
Exactly the same procedure was repeated with the exclusion of the addition of Con A and LPS.

\section{Macrophage Isolation From Peritoneal Fluid}

Forty-eight hours before collection of peritoneal macrophages (PEM), mice were injected intra-peritoneally injected with $1 \mathrm{~mL}$ of $6 \%$ starch broth medium. Mice were euthanized by cervical dislocation and their abdominal cavities were visualized then $5 \mathrm{ml}$ ice-cold PBS was introduced into the cavity. After gentle massaging the fluid was withdrawn and placed in a centrifuge. After centrifugation of the pooled fluid, cell pellet was suspended in complete RPMI 1640 medium and allowed to adhere for $3 \mathrm{~h}$ at $37^{\circ} \mathrm{C}$ in $5 \% \mathrm{CO}_{2}$ humidified incubator. Thereafter, non-adherent cells were washed away with medium and the adherent cells then collected and counted to be used in the various assays outlined below (25).

\section{IN VITRO PHAGOCYTIC ASSAY [NITRO BLUE TETRAZOLIUM (NBT) REDUCTION TEST]}

The phagocytic activity of macrophage was evaluated using NBT reduction assay. This assay was carried out according to the method previously described by Rainard (26). In brief, PEM (5 $\times 10^{6}$ cells/well of a 96-well plate) were cultured with different concentrations of T. boudieri extracts $(25-3.125 \mathrm{mg} / \mathrm{ml})$ for $48 \mathrm{~h}$. Thereafter, $20 \mu \mathrm{l}$ yeast suspension $\left(5 \times 10^{7}\right.$ cells $/ \mathrm{ml}$ in PBS $)$ and

TABLE 1 | The percentage yield obtained from the extraction of $250 \mathrm{~g}$ of T. boudieri using different extraction solvents.

\begin{tabular}{lllc}
\hline & $\begin{array}{l}\text { Extraction } \\
\text { method }\end{array}$ & $\begin{array}{l}\text { Extraction } \\
\text { solvent }\end{array}$ & $\begin{array}{c}\text { \% of dried } \\
\text { extracts yields }\end{array}$ \\
\hline Maceration & Aqueous/methanol & 8.16 \\
T. boudieri & Wractionation & Water & 64.7 \\
& & n-hexane & 1.2 \\
& & Ethyl & 0.4
\end{tabular}

$20 \mu \mathrm{l}$ nitro blue tetrazolium (NBT) $(1.5 \mathrm{mg} / \mathrm{ml}$ in $\mathrm{PBS})$ were added to each well. Wells that received $20 \mu \mathrm{l}$ PBS and $20 \mu \mathrm{l}$ DMSO were used as negative controls. Cells were then incubated for $60 \mathrm{~min}$ at $37^{\circ} \mathrm{C}$, and the supernatant was then removed and the adherent macrophages were rinsed with RPMI 1640. The cells were air-dried before $120 \mu \mathrm{l}$ of $2 \mathrm{M} \mathrm{KOH}$ and $140 \mu \mathrm{l}$ DMSO were added to each well. The absorbance of the turquoise blue solution was measured at $570 \mathrm{~nm}$ (OD570) in the plate reader. The percentage of NBT reduction (reflects phagocytic activity) was calculated as following equation (24):

$$
\begin{aligned}
\text { Phagocytic index }= & (\text { OD sample }- \text { OD control }) / \\
& \text { OD control }{ }^{*} 100
\end{aligned}
$$

\section{PINOCYTIC ACTIVITY ASSAY BY NEUTRAL RED METHOD}

Peritoneal mice macrophages were collected and cultured for $48 \mathrm{~h}$ with variant concentrations of $T$. boudieri extracts (25-3.125 $\mathrm{mg} / \mathrm{ml}$ ) using 96-well plate. One hundred microliter of neutral red solution $(7.5 \mathrm{mg} / \mathrm{ml}$ in PBS) were added to each well and incubated for $2 \mathrm{~h}$. The supernatant was discarded and cells in 96well plate were washed with PBS twice to remove the neutral red that was not pinocytized by macrophage. Then, $100 \mu \mathrm{l}$ of cell lysis solution (ethanol and $0.01 \%$ acetic acid at the ratio of $1: 1$ ) were added to each well to lyse cells. After the incubation of cells at room temperature overnight, the optical density was measured at $540 \mathrm{~nm}$. Pinocytic activity was expressed in terms of absolute OD values (reflecting dye uptake) (24).

\section{STATISTICAL ANALYSIS}

Data are presented using mean \pm SEM (Standard Error of Mean). The statistical significance among the groups was determined by one-way analysis of variance (ANOVA) using SPSS (Statistical Package for the Social Science, Chicago, Illinois). A $p<0.05$ was considered significant. The $\mathrm{IC}_{50}$ was obtained for the different extracts of $T$. boudieri using non-linear regression in SPSS (version 21).

TABLE 2 | Phytochemical screening results obtained from the extraction of T. boudieri using different extraction solvents (a concentration of $50 \mathrm{mg} / \mathrm{ml}$ was used for each

\begin{tabular}{|c|c|c|c|c|}
\hline \multirow[t]{2}{*}{ Phytochemical screening tests* } & \multicolumn{4}{|c|}{ T. boudieri } \\
\hline & Aqueous/methanol & Aqueous & n-hexane & Ethyl acetate \\
\hline Saponins & - & - & - & - \\
\hline Tannins & +++ & ++ & - & - \\
\hline Terpenoids & + & ++ & ++ & +++ \\
\hline Phytosterols & + & ++ & ++ & +++ \\
\hline Alkaloids & ++ & +++ & - & - \\
\hline Flavonoids & + & ++ & - & - \\
\hline Anthraquinones & - & - & - & - \\
\hline Carbohydrates & ++ & +++ & ++ & + \\
\hline
\end{tabular}
extract).

${ }^{*}$ Results were rated as: ${ }^{+}$weak positive; ${ }^{++}$moderate positive; ${ }^{+++}$strong positive; -, negative. 


\section{RESULTS}

\section{Aqueous and Aqueous/Methanol Extracts} Produced the Highest Yield and Contain Alkaloids and Flavonoids

High variations in percentage yield were observed upon the extraction of $250 \mathrm{gm}$ of $T$. boudieri, using different extraction solvents (Table 1). By using maceration method, the percentage yield reported for $T$. boudieri aqueous/methanol extract was (8.16\%). Then by fractionation method for $T$. boudieri aqueous/methanol extract using water, $n$-hexane, and ethyl acetate solvents, the highest yield was reported for aqueous extract $(64.7 \%)$, while the lowest yield was reported for ethyl acetate extract $(0.4 \%)$.
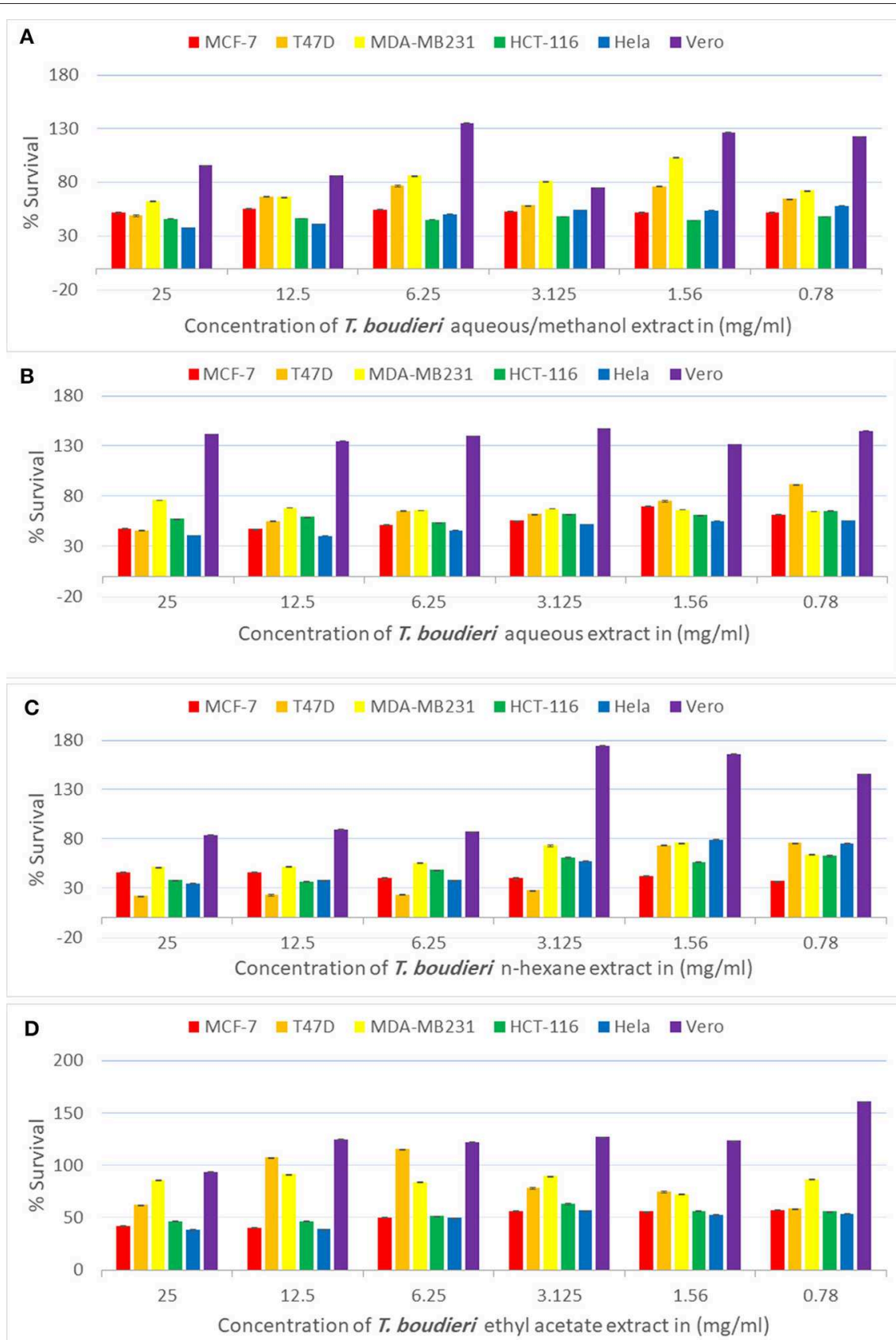

FIGURE 1 | (A) Antiproliferative activity of aqueous/methanol extract of T. boudieri on MCF-7, T47D, MDA-MB231, HCT-116, Hela and Vero cell lines. (B) Antiproliferative activity of aqueous extract of T. boudieri on MCF-7, T47D, MDA-MB231, HCT-116, Hela and Vero cell lines. (C) Antiproliferative activity of n-hexane extract of T. boudieri on MCF-7, T47D, MDA-MB231, HCT-116, Hela and Vero cell lines. (D) Antiproliferative activity of ethyl acetate extract of T. boudieri on MCF-7, T47D, MDA-MB231, HCT-116, Hela and Vero cell lines. Results are expressed as means of three independent experiments (bars) \pm SEM (lines). 
The qualitative phytochemical screening results revealed that terpenoids, phytosterols, and carbohydrates were present in all the solvent extracts, while saponins and anthraquinones were absent in all extracts. Tannins, alkaloids, and flavonoids were detected only in aqueous/methanol and aqueous extracts (Table 2).

\section{$\mathrm{N}-$ Hexane and Ethyl Acetate Extracts Showed the Highest Antiproliferative Activity Against All Cell Lines}

Testing decreasing concentrations of $T$. boudieri extracts (25$0.78 \mathrm{mg} / \mathrm{ml}$ ) on MCF-7 cell line resulted in a dose-dependent manner. The inhibition percentages of queous/methanol, aqueous, n-hexane and ethyl acetate extracts were $49,43,54$, and $52 \%$, respectively (Figures 1A-D) at concentration of $25 \mathrm{mg} / \mathrm{ml}$ for each extract. N-hexane and ethyl acetate extracts showed the highest activity with $\mathrm{IC}_{50}$ values of $<0.78 \mathrm{mg} / \mathrm{ml}$, while aqueous/methanol and aqueous extracts were the least effective against MCF-7 cell line with $\mathrm{IC}_{50}$ values more than $25 \mathrm{mg} / \mathrm{ml}$ (Table 3).

For T47D cells, the inhibition percentages of aqueous/methanol, aqueous, n-hexane and ethyl acetate extracts were 69, 61, 61, and 71\%, respectively (Figures 1A-D). at concentration of $25 \mathrm{mg} / \mathrm{ml}$. Aqueous/methanol, aqueous, n-hexane and ethyl acetate extracts showed high activity against T47D cell line with $\mathrm{IC}_{50}$ values of $8.5,13,<0.78$, and $8 \mathrm{mg} / \mathrm{ml}$, respectively (Table 3). For MDA-MB231 cell line, the inhibition percentages of aqueous/methanol, aqueous, n-hexane, and ethyl acetate extracts were $38,25,49$, and $14 \%$, respectively at concentration of $25 \mathrm{mg} / \mathrm{ml}$ (Figures 1A-D). Most extracts were less effective against MDA-MB231 cell line with $\mathrm{IC}_{50}$ values more than $25 \mathrm{mg} / \mathrm{ml}$ (Table 3). However, n-hexane extract exhibited high activity against this cell line with IC50 value of $3.75 \mathrm{mg} / \mathrm{ml}$.

A dose dependent inhibition for all extracts was also observed in HCT-116, Hela, and VERO cell lines with lower toxicity toward VERO cells (Figure 1 and Table 3).

TABLE 3 | The $\mathrm{IC}_{50}(\mathrm{mg} / \mathrm{ml})$ for different extracts of $T$. boudieri tested on six different cell lines (MCF-7, T47D, MDA-MB231, HCT-116, Hela, and Vero).

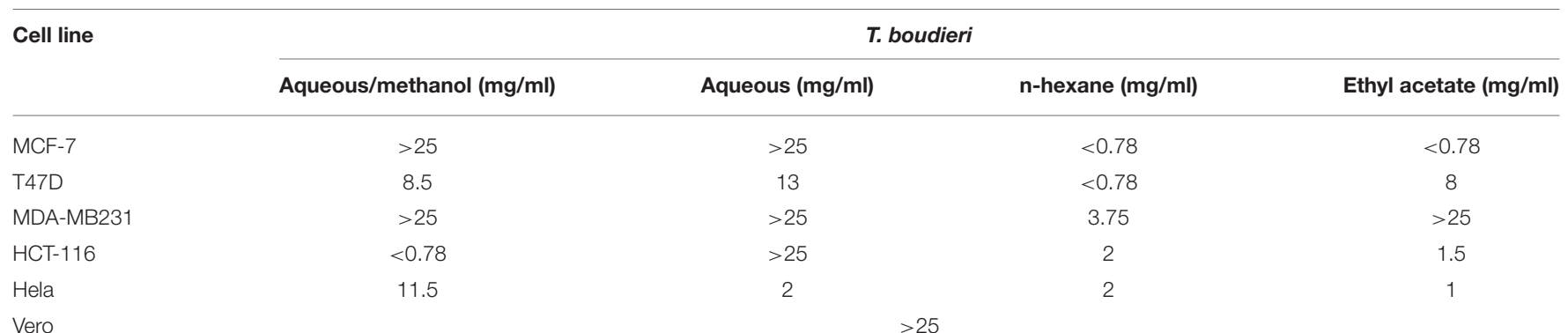

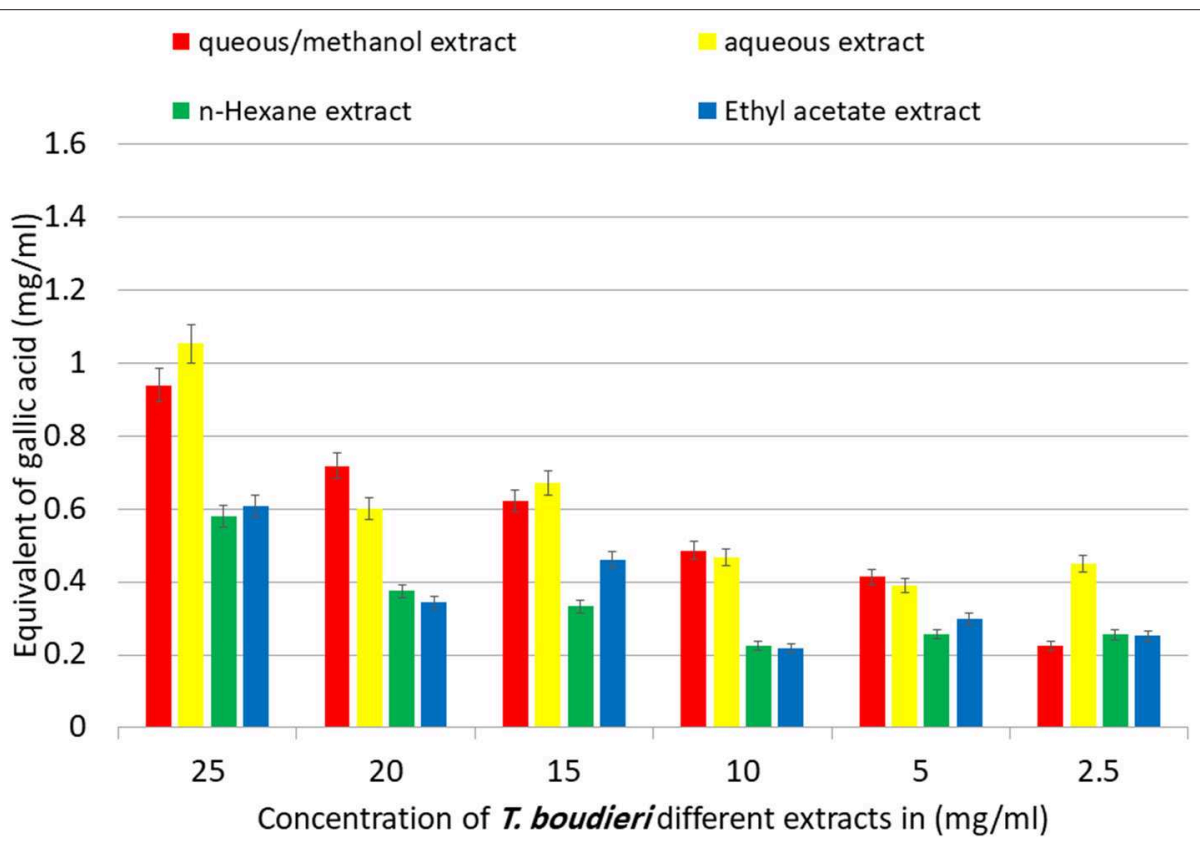

FIGURE 2 | Equivalent of gallic acid in $\mathrm{mg}$ per $1 \mathrm{ml}$ of aqueous/methanol, aqueous, n-hexane, and ethyl acetate extracts of T. boudieri in different concentrations. Results are expressed as means of three independent experiments (bars) \pm SEM (lines). 


\section{Aqueous/Methanol and Aqueous Extracts Have the Highest Phenolic Content}

The TPC in T. boudieri extracts was determined according to the Folin-Ciocalteu procedure. The TPC were increasing in a concentration dependent manner. The aqueous/methanol and aqueous extracts showed the highest equivalent of gallic acid with values of 0.94 and $1.05 \mathrm{mg} / \mathrm{ml}$, respectively. On the other hand, n-hexane and ethyl acetate extracts showed lower equivalent of gallic acid with values of 0.58 and $0.61 \mathrm{mg} / \mathrm{ml}$, respectively (Figure 2).

\section{T. boudieri Inhibits Angiogenesis by Inhibiting VEGF Expression}

The expression of VEGF was measured in vitro in T47D cell line in order to investigate whether the inhibition of angiogenesis may contribute to the observed antiproliferative effect. In the negative control group, VEGF was highly expressed (371 pg/ml). Treating cells with aqueous/methanol extract $(12.5 \mathrm{mg} / \mathrm{ml})$ decreased VEGF expression level to $203 \mathrm{pg} / \mathrm{ml}$, while doxorubicin (250 nM) showed a VEGF expression level of 309 pg/ml (Figure 3).

\section{T. boudieri Induces Apoptosis by Increasing Caspase-3 Activity}

Apoptosis induction in treated cells was measured using caspase3 activity assay. The aqueous/methanol extract $(25 \mathrm{mg} / \mathrm{ml})$ increased caspase- 3 activity by 4.85 -folds of negative control, while doxorubicin $(250 \mathrm{nM})$ showed an increase of 2.57 -folds of the negative control (Figure 4).

\section{T. boudieri Increases the Level of IFN- $\gamma$ and IL-2}

The immuno-modulatory effect of different extracts was evaluated by measuring levels of IFN- $\gamma$, IL-4, IL-2, and IL-10 in lymphocytes treated with different solvent extracts of $T$. boudieri.

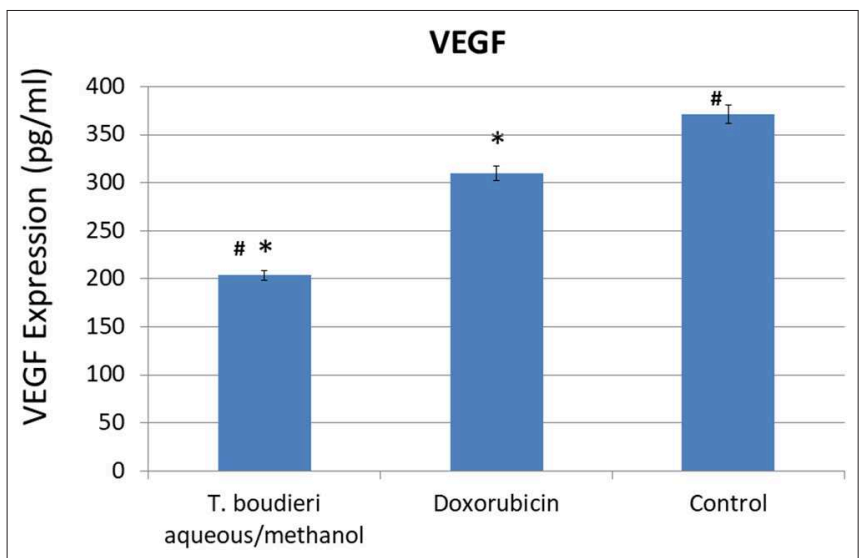

FIGURE 3 | The effect of T. boudieri aqueous/methanol extract (at a concentration of $12.5 \mathrm{mg} / \mathrm{ml}$ ) and doxorubicin $(250 \mathrm{nM}$ ) on VEGF (vascular endothelial growth factor) expression (pg/ml) in T47D cells. Results are expressed as means of three independent experiments (bars) \pm SEM (lines). The asterisks represent significant difference compared with the negative control ( ${ }^{\star} P<0.05$ ); compared with doxorubicin treatment ( ${ }^{\#} P<0.05$ ).
The results indicate that there is significant increase in IFN $-\gamma$ and IL-2 in lymphocytes treated with $25 \mathrm{mg} / \mathrm{ml}$ of different solvent extracts compared with the control group. The highest level of IFN- $\gamma$ was observed in lymphocytes treated with $\mathrm{n}$-hexane. While aqueous/methanol extract induced the highest increase in (Figure 5).

\section{T. boudieri Stimulates Lymphocytes Proliferation in the Presence and Absence of Mitogens}

Our experimental findings showed that most of $T$. boudieri extracts induced an increase in lymphocytes cell proliferation in the presence of Con A and LPS (Figure 6). At a concentration of $25 \mathrm{mg} / \mathrm{ml}$, the most active extract was ethyl acetate with a percentage of cell viability of $120 \%$ and 116 on Con A and LPS stimulated cells, respectively. Other solvent extracts showed variable activities (Figure 6). In the absence of mitogenic stimulation, our results showed that all $T$. boudieri extracts induced an increase in lymphocytes cell proliferation with stimulation level reaching $143 \%$ for cells treated with ethyl acetate extract (Figure 7).

\section{T. boudieri Enhances Phagocytic and Pinocytic Activity of Peritoneal Macrophages}

Phagocytic activity of peritoneal macrophages was determined by measuring of NBT reduction ability after treatment with different extracts. Aqueous/methanol extract showed the highest stimulation of peritoneal phagocytic activity at dose of $25 \mathrm{mg} / \mathrm{ml}$ (Figure 8). The results of pinocytic assay showed that the effect of most extracts was stimulatory compared with the negative

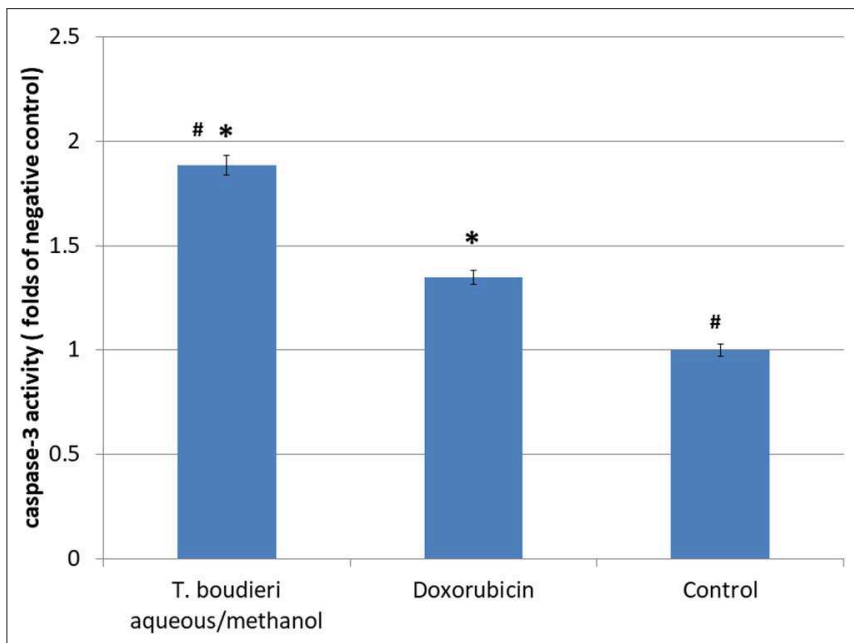

FIGURE 4 | The effect of T. boudieri aqueous/methanol extract (at a concentration of $25 \mathrm{mg} / \mathrm{ml}$ ) and doxorubicin $(250 \mathrm{nM})$ on caspase 3 activity expressed by number of folds of negative control. Results are expressed as means of 3 independent experiments (bars) \pm SEM (lines). The asterisks represent significant difference compared with the negative control $\left({ }^{\star} P<0.05\right)$; compared with doxorubicin treatment ( $\# P<0.05$ ). 

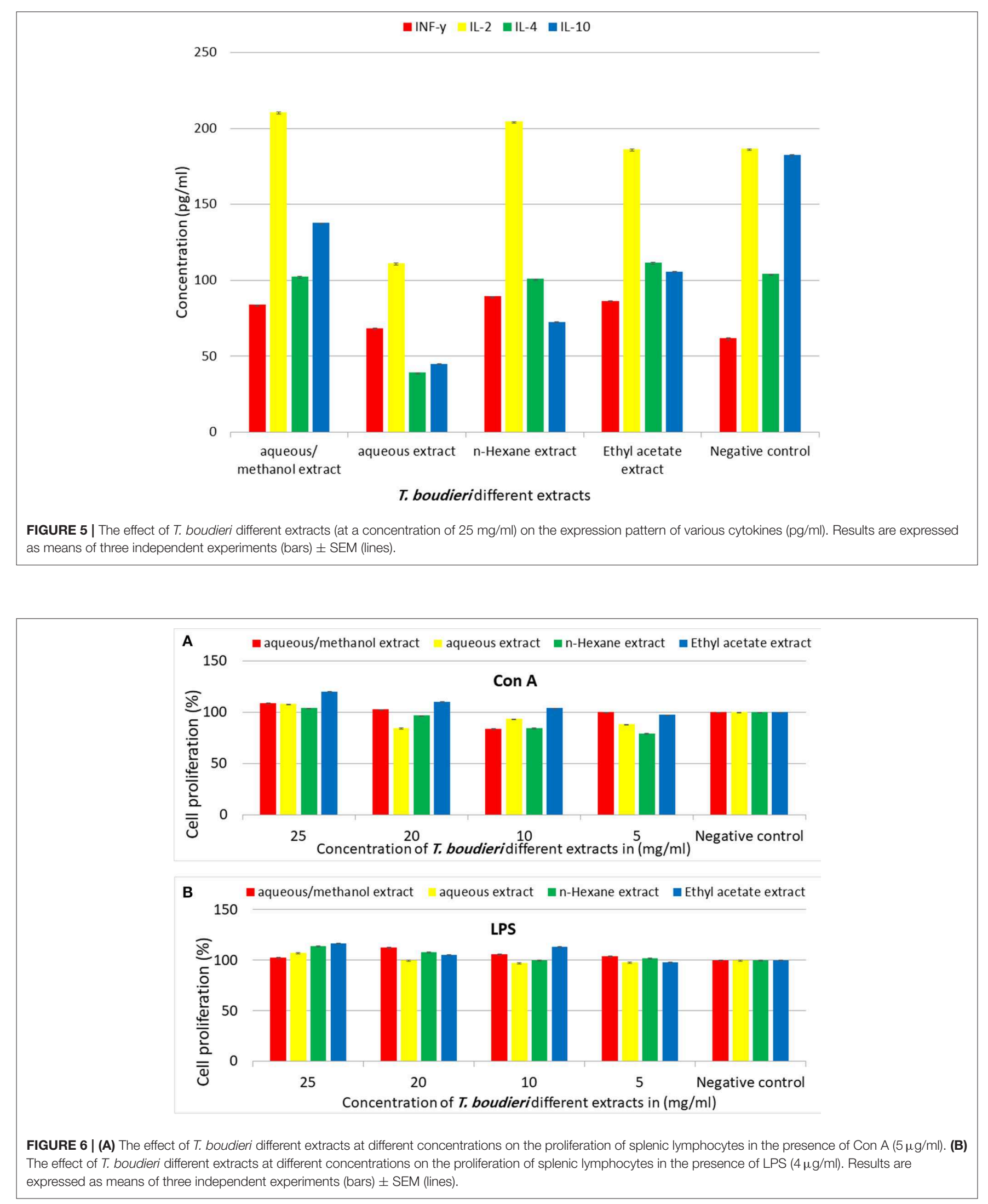
control at the doses ranged from 3.125 to $25 \mathrm{mg} / \mathrm{ml}$. Ethyl acetate extract caused the highest increase in the pinocytic activity with value of compared to control (Figure 9).

\section{DISCUSSION}

The wild edible fungi (WEF) are an important group of nonwood forest products. The history of using WEF is well recorded and highly valued. The biological activities within the fungi

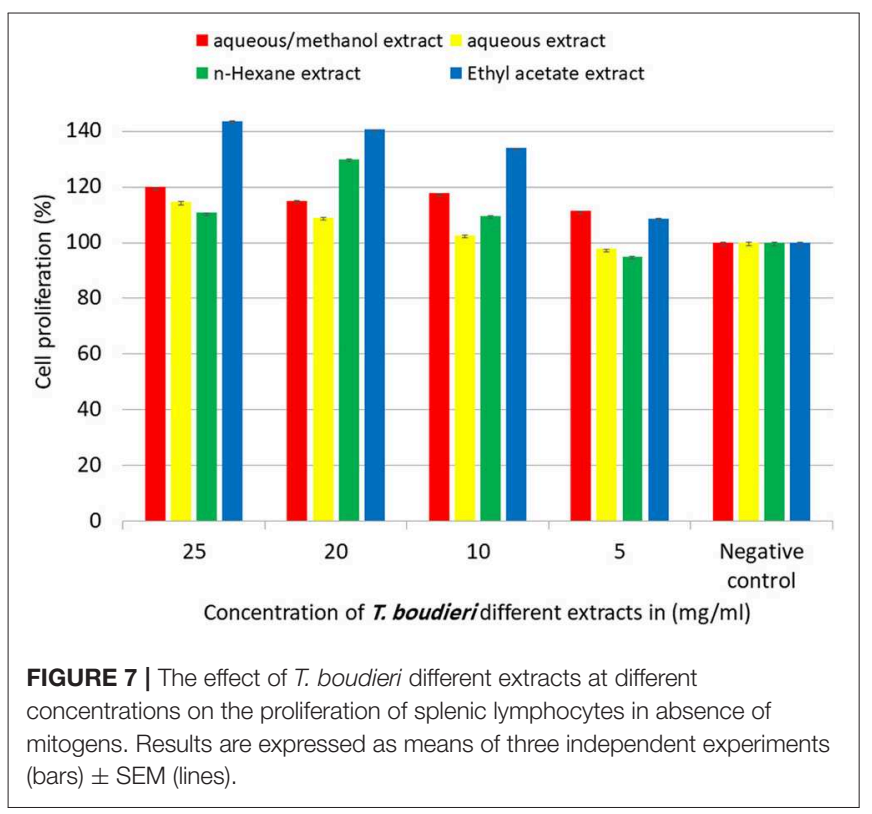

kingdom (both truffles and mushrooms) are widely accepted and applied as main component of folk medicine (14).

In our study, we evaluated the anticancer activity and immune modulation effect of $T$. boudieri which is largely used in Middle East as food and to prevent different ailments. Most extracts showed positive results and exhibited immunomodulatory and/or anticancer activities.

In the anticancer part, $\mathrm{n}$-hexane extract was active against all cell lines, while ethyl acetate extract was active against all cell lines except MDA-MB-231. Other solvent extracts showed variable activity against different cell lines (Figure 1). We also noticed a variation in the $\mathrm{IC}_{50}$ values of the same extract against different cell lines (Table 3). Previous studies attribute this selectivity to the sensitivity of the cell lines to the nature of the active compounds in these extracts or to the tissue specific response $(27,28)$.

Studies are very limited for $T$. boudieri anticancer activity. However, many previous studies detected chemical compounds in $n$-hexane extract of $T$. claveryi which is closely related to $T$ boudieri. Campestanol, stigmasterols, and beta-sitosterol are phytosterols found in this extract (29). Phytosterols (naturally occurring steroids) are involved in many mechanisms of action, such as promotion of cancer cells apoptosis, angiogenesis inhibition and inhibiting cancer-cell growth (30).

In our study, the superior activity of n-hexane extract could be explained by the presence of phytosterols which was detected in our phytochemical screening results that showed strong positive result for phytosterol in n-hexane extract (Table 2).

Our results showed a variation of total phenolic content (TPC) from extract to another with a best result for aqueous and aqueous/methanol extracts (Figure 2). Phenolic compounds diminish the initiation, progression, and spread of cancer cells

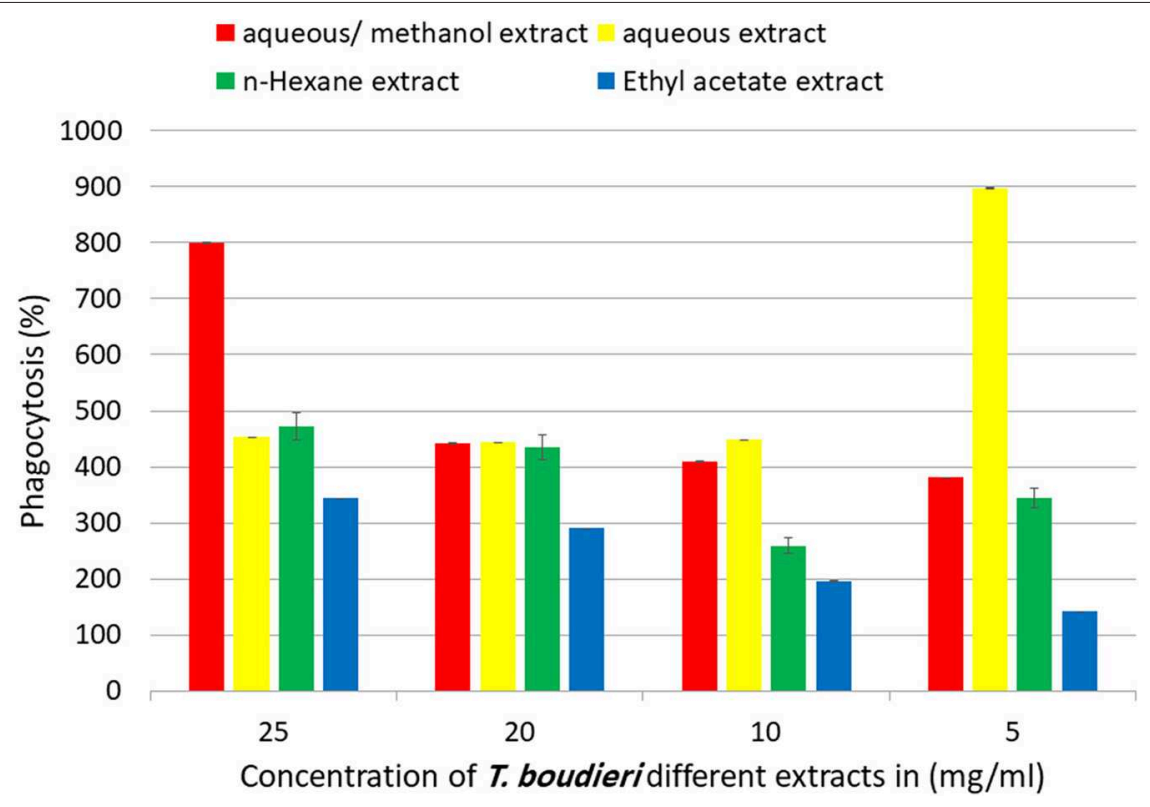

FIGURE 8 | In vitro phagocytic assay using nitro blue tetrazolium (NBT) reduction test of peritoneal macrophage treated with various concentrations of T. boudieri extracts for $48 \mathrm{~h}$. Results are expressed as means of three independent experiments (bars) \pm SEM (lines). 


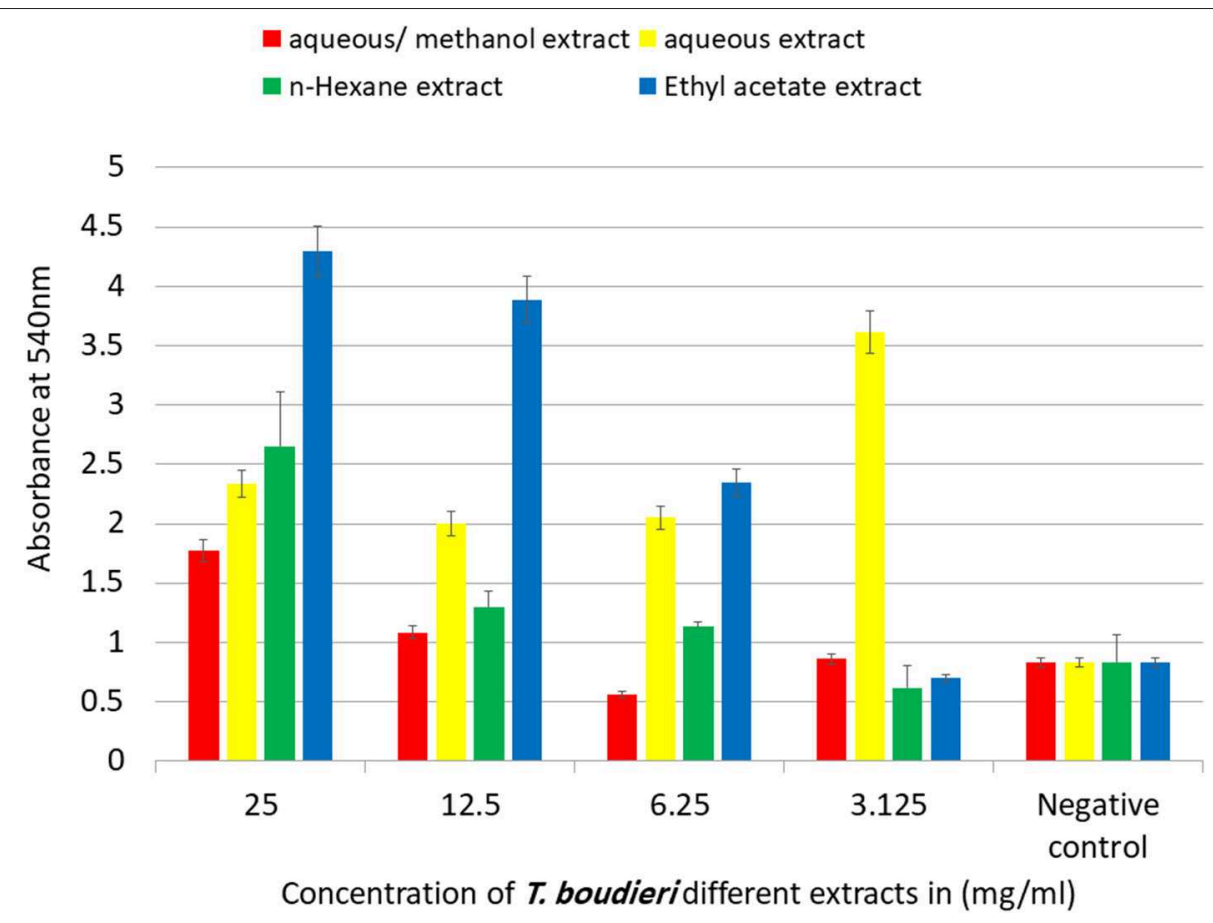

FIGURE 9 | The effect of T. boudieri different extracts on macrophage pinocytosis. Results are expressed as means of three independent experiments (bars) \pm SEM (lines).

in vitro and in vivo. The mechanisms that phenolics modulate to achieve these anticancer effects are multi-faceted, including cell signaling cascades and regulation of growth factor-receptor interactions, which involve transcription factors and kinases, that determine genes expression involved in cell survival, cell cycle arrest and apoptosis (31).

All extracts were not active against MDA-MB231 cell line except $\mathrm{n}$-hexane extract which showed only a mild activity. This may be explained by the features of MDAMB231 cell line, which is characterized by the absence of the expression of ER (oestrogen receptor), PR (progesterone receptor), and HER2 (human epidermal growth factor receptor 2), sometimes it is mentioned as triple-negative. The lack of the expression of a recognized therapeutic target, makes MDA-MB231 more biologically aggressive, difficult to treat and often have a poor prognosis (32). On the other hand, all of the extracts showed low activity against Vero normal cells as indicated by high $\mathrm{IC}_{50}$ values, this may indicate safety of these extracts against normal cell (Table 3).

Vascular endothelial growth factor (VEGF) is a protein that stimulates the formation of blood vessels (angiogenesis process). This protein is an important target in cancer treatment to inhibit cancer cells proliferation by the prevention of blood vessels formation (33). Aqueous/methanol extract exhibited high activity to inhibit angiogenesis, compared to doxorubicin (positive control) (Figure 3). The phytochemical test showed positive results for phenols in aqueous/methanol extract. This result agrees with previous studies which confirm the potential activity of phenols in decreasing the risk of developing many types of cancer and decreasing the risk of cancer progression, due to their ability to decrease vascular endothelial growth factor (VEGF) expression and cell viability (34).

The induction of apoptosis is another mechanism responsible for anticancer activity. It is highly organized and controlled process and helps the body in maintaining its homeostasis (35). In cancer, this process is not working properly due to induction of the anti-apoptotic gene and inhibition of the proapoptotic gene thus the cell division and proliferation will continue (36). In our study, the aqueous/methanol extract of $T$. boudieri induced apoptosis by enhancing caspase- 3 activity. Such result could be explained by the presence of phenols, steroids, terpenoids, and carbohydrates in this extract. These compounds exhibit clear apoptosis induction ability as indicated by previous studies $(37,38)$.

The immune system is a complex defense system in vertebrates. It contains a sophisticated network of cells, tissues and organs that work together to defend the body from foreign invaders such as bacteria, fungi, and parasites that can cause infections (39).

In our study, variations in immune response due to exposure to truffle extracts were also explored through measuring levels of IFN- $\gamma$, IL-2, IL-4, and IL-10. The current results indicate that there is an up-regulation in IFN- $\gamma$ and IL-2 in lymphocytes treated with some truffle extracts (Figure 5). High levels of IFN- $\gamma$ and IL-2 indicates stimulation of Th1 immune response which is important in anticancer immune 
response. On the other hand, high IL-4 stimulates Th2 immune response (40). Our results showed that different solvent extracts of $T$. boudieri can stimulate the immune system toward Th1. N-hexane extract showed the highest effect, followed by ethyl acetate and aqueous/methanol extracts (Figure 5). Many studies mentioned the immunomodulatory effect of truffle species $(41,42)$, and this confirm our results. This effect may be explained by the presence of different phytochemicals in truffle extracts.

Lymphocytes proliferation assay was conducted to measure the effect of each extract on lymphocytes proliferation and activation. Ethyl acetate extract showed the highest effect as a stimulator of lymphocytes (Figures 6, 7). This extract is rich in terpenoids which may explain its activity. A previous study showed that monoterpene enhances splenocytes proliferation in Balb/C mice (43).

Phagocytic activity test and pinocytic activity test were conducted to evaluate the effect of each extract on innate immunity. Macrophages play an important role in phagocytosis which is responsible for the intracellular killing of antigen and other apoptotic cells. Therefore, the modulation of macrophage activity seems to play a chief role in regulation of innate immunity (44). The aqueous/methanol extract showed the highest stimulation, followed by n-hexane, aqueous, and ethyl acetate extracts (Figures 8, 9). The high activity of aqueous/methanol extract may be explained by the presence of flavonoids in these extracts, as mentioned previously in our phytochemical tests. A previous study on flavonoids indicates that they can enhance macrophage function (45).

\section{REFERENCES}

1. WH. Melatonin and cancer hallmarks. Molecules. (2018) 23:518. doi: $10.3390 /$ molecules 23030518

2. World Health Organization. WHO Traditional Medicine Strategy 2002-2005. Geneva: World Health Organization (2002).

3. Richardson DB, Cardis E, Daniels RD, Gillies M, O’Hagan JA, Hamra GB, et al. Risk of cancer from occupational exposure to ionising radiation: retrospective cohort study of workers in France, the United Kingdom, and the United States (INWORKS). BMJ. (2015) 351:h5359. doi: 10.1136/bmj. h5359

4. Stewart BW, Wild CP. World Cancer Report. World Health Organization (2014). doi: 10.12968/nuwa.2014.10.2.1142051

5. Talib WH. Consumption of garlic and lemon aqueous extracts combination reduces tumor burden by angiogenesis inhibition, apoptosis induction, and immune system modulation. Nutrition. (2017) 43:89-97. doi: 10.1016/j.nut.2017.06.015

6. Block KI, Gyllenhaal C, Lowe L, Amedei A, Amin AR, Amin $A$, et al. Designing a broad-spectrum integrative approach for cancer prevention and treatment. Semin Cancer Biol. (2015) 35:S276-304. doi: 10.1016/j.semcancer.2015.08.002

7. Turati F, Rossi M, Pelucchi C, Levi F, La Vecchia C. Fruit and vegetables and cancer risk: a review of southern European studies. Brit J Nutr. (2015) 113:S102-10. doi: 10.1017/S0007114515000148

8. Talamini R, Franceschi S, La Vecchia C, Serraino D, Barra S, Negri E. Diet and prostatic cancer: a case-control study in northern Italy. Nutr Cancer. (1992) 18:277-86. doi: 10.1080/01635589209514228

9. Talib WH, Abukhader M. Combinatorial effects of thymoquinone on the anticancer activity and hepatotoxicity of the prodrug CB 1954. Sci Pharm. (2013) 81:519-30. doi: 10.3797/scipharm.1211-15

\section{CONCLUSION}

Terfezia boudieri is a truffle rich in biologically active phytochemicals. It contains compounds with anticancer and immunomodulatory effects. The anticancer activity of its extracts is mediated by angiogenesis inhibition and apoptosis induction. The immunomodulatory effect is mediated by activation of innate and acquired arms of the immune system. Further studies are needed to isolate and identify pure active compounds from this truffle to fully understand its anticancer and immunomodulatory effects.

\section{DATA AVAILABILITY STATEMENT}

The datasets generated for this study are available on request to the corresponding author.

\section{AUTHOR CONTRIBUTIONS}

The project idea was developed by WT. The experimental design was developed by WT and WH. Sample collections were performed by MA. The laboratory experiments were run by MA. The data were analyzed by WT, LA, and MA. The manuscript was written and revised by WT, LA, and MA.

\section{ACKNOWLEDGMENTS}

The authors are grateful to the Applied Science Private University, Amman, Jordan for the full financial support granted to this research project.

10. Talib W. Regressions of breast carcinoma syngraft following treatment with piperine in combination with thymoquinone. Sci Pharm. (2017) 85:27. doi: $10.3390 /$ scipharm85030027

11. Wasser SP, Sokolov D, Reshetnikov SV, Timor-Tismenetsky M. Dietary supplements from medicinal mushrooms: diversity of types and variety of regulations. Int J Med Mushrooms. (2000) 2. doi: 10.1615/IntJMedMushr.v2.i1.10

12. Markman JL, Shiao SL. Impact of the immune system and immunotherapy in colorectal cancer. J Gastrointestinal Oncol. (2015) 6:208-23. doi: 10.3978/j.issn.2078-6891.2014.077

13. Petrova RD, Reznick AZ, Wasser SP, Denchev CM, Nevo E, Mahajna J. Fungal metabolites modulating NF-кB activity: an approach to cancer therapy and chemoprevention. Oncol Rep. (2008) 19:299-308. doi: 10.3892/or.19.2.299

14. El Enshasy HA, Hatti-Kaul R. Mushroom immunomodulators: unique molecules with unlimited applications. Trends Biotechnol. (2013) 31:66877. doi: 10.1016/j.tibtech.2013.09.003

15. Patel S, Goyal A. Recent developments in mushrooms as anti-cancer therapeutics: a review. 3Biotech. (2012) 2:1-5. doi: 10.1007/s13205-011-0036-2

16. Hamza A, Zouari N, Zouari S, Jdir H, Zaidi S, Gtari M, et al. Nutraceutical potential, antioxidant and antibacterial activities of Terfezia boudieri Chatin, a wild edible desert truffle from Tunisia arid zone. Arab J Chem. (2016) 9:383-9. doi: 10.1016/j.arabjc.2013.06.015

17. Akyüz M. Nutritive value, flavonoid content and radical scavenging activity of the truffle (Terfezia boudieri Chatin). J Soil Sci Plant Nutr. (2013) 13:14351. doi: 10.4067/S0718-95162013005000013

18. Trease and Evans. Pharmacognosy, International Edition E-Book. Nottingham: Elsevier Health Sciences (2009).

19. Molan AL, Flanagan J, Wei W, Moughan PJ. Selenium-containing green tea has higher antioxidant and prebiotic activities than regular green tea. Food Chem. (2009) 114:829-35. doi: 10.1016/j.foodchem.2008.10.028 
20. Sabbah DA, Al-Tarawneh F, Talib WH, Sweidan K, Bardaweel SK, AlShalabi E, et al. Benzoin schiff bases: Design, synthesis, and biological evaluation as potential antitumor agents. Med Chem. (2018) 14:695708. doi: 10.2174/1573406414666180412160142

21. Talib WH, Al Kury LT. Parthenolide inhibits tumor-promoting effects of nicotine in lung cancer by inducing P53-dependent apoptosis and inhibiting VEGF expression. Biomed Pharmacother. (2018) 107:148895. doi: 10.1016/j.biopha.2018.08.139

22. Sabbah DA, Ibrahim AH, Talib WH, Alqaisi KM, Sweidan K, Bardaweel SK, et al. Ligand-based drug design: synthesis and biological evaluation of substituted benzoin derivatives as potential antitumor agents. Med Chem. (2019) 15:417-29. doi: 10.2174/1573406414666180912111846

23. Falah RR, Talib WH, Shbailat SJ. Combination of metformin and curcumin targets breast cancer in mice by angiogenesis inhibition, immune system modulation and induction of $\mathrm{p} 53$ independent apoptosis. Therapeut Adv Med Oncol. (2017) 9:235-52. doi: 10.1177/1758834016687482

24. Boothapandi MA, Ramanibai RA. Immunomodulatory activity of Indigofera tinctoria leaf extract on in vitro macrophage responses and lymphocyte proliferation. Int J Pharm Pharmaceut Sci. (2016) 8:58-63.

25. Liu Z, Xing J, Huang Y, Bo R, Zheng S, Luo L, et al. Activation effect of Ganoderma lucidum polysaccharides liposomes on murine peritoneal macrophages. Int J Biol Macromol. (2016) 82:973-8. doi: 10.1016/j.ijbiomac.2015.10.088

26. Rainard P. A colorimetric microassay for opsonins by reduction of NBT in phagocytosing bovine polymorphs. J Immunol Methods. (1986) 90:197201. doi: 10.1016/0022-1759(86)90076-1

27. Talib W., Mahasneh A. Antiproliferative activity of plant extracts used against cancer in traditional medicine. Sci Pharm. (2010) 78:33-46. doi: 10.3797/scipharm.0912-11

28. Kirana C, Record IR, McIntosh GH, Jones GP. Screening for antitumor activity of 11 species of Indonesian zingiberaceae using human MCF-7 and HT-29 cancer cells. Pharmaceut Biol. (2003) 41:271-6. doi: 10.1076/phbi.41.4.271.15673

29. Dahham SS, Al-Rawi SS, Ibrahim AH, Majid AS, Majid AM. Antioxidant, anticancer, apoptosis properties and chemical composition of black truffle Terfezia claveryi. Saudi J Biol Sci. (2018) 25:1524-34. doi: 10.1016/j.sjbs.2016.01.031

30. Woyengo TA, Ramprasath VR, Jones PJ. Anticancer effects of phytosterols. Eur J Clin Nutr. (2009) 63:813. doi: 10.1038/ejcn.2009.29

31. Wahle KW, Brown I, Rotondo D, Heys SD. Plant phenolics in the prevention and treatment of cancer. Bio Farms Nutraceut. (2010) 698:3651. doi: 10.1007/978-1-4419-7347-4_4

32. Holliday DL, Speirs V. Choosing the right cell line for breast cancer research. Breast Cancer Res. (2011) 13:215. doi: 10.1186/bcr2889

33. Shinkaruk S, Bayle M, Lain G, Deleris G. Vascular endothelial cell growth factor (VEGF), an emerging target for cancer chemotherapy. Curr Med Chem AntiCancer Agents. (2003) 3:95-117. doi: 10.2174/1568011033353452
34. He Z, Li B, Rankin GO, Rojanasakul Y, Chen YC. Selecting bioactive phenolic compounds as potential agents to inhibit proliferation and VEGF expression in human ovarian cancer cells. Oncol Lett. (2015) 9:144450. doi: $10.3892 / \mathrm{ol} .2014 .2818$

35. Talib WH, Zarga MH, Mahasneh AM. Antiproliferative, antimicrobial and apoptosis inducing effects of compounds isolated from Inula viscosa. Molecules. (2012) 17:3291-303. doi: 10.3390/molecules17033291

36. Hanahan D, Weinberg RA. Hallmarks of cancer: the next generation. Cell. (2011) 144:646-74. doi: 10.1016/j.cell.2011.02.013

37. $\mathrm{Xu} \mathrm{H}, \mathrm{Xu} \mathrm{X}$. Polysaccharide, a potential anti-cancer drug with high efficacy and safety. Adv Oncol Res Treat. (2016) 2:2.

38. Li X, Wu Q, Xie Y, Ding Y, Du WW, Sdiri M, et al. Ergosterol purified from medicinal mushroom Amauroderma rude inhibits cancer growth in vitro and in vivo by up-regulating multiple tumor suppressors. Oncotarget. (2015) 6:17832. doi: 10.18632/oncotarget.4026

39. Dasgupta D. Advances in artificial immune systems. IEEE Comput Intell Mag. (2006) 1:40-9. doi: 10.1109/CI-M.2006.248056

40. Talib WH, Saleh S. Propionibacterium acnes augments antitumor, anti-angiogenesis and immunomodulatory effects of melatonin on breast cancer implanted in mice. PLoS ONE. (2015) 10:e0124384. doi: 10.1371/journal.pone.0124384

41. Owaid MN. Bioecology and uses of desert truffles (Pezizales) in the Middle East. Walailak J Sci Technol. (2017) 15:179-88.

42. Gajos M, Ryszka F, Geistlinger J. The therapeutic potential of truffle fungi: a patent survey. Acta Mycol. (2014) 49:2. doi: 10.5586/am.2014.022

43. Siveen KS, Kuttan G. Augmentation of humoral and cell mediated immune responses by Thujone. Int Immunopharmacol. (2011) 11:196775. doi: 10.1016/j.intimp.2011.08.006

44. Delcenserie V, Martel D, Lamoureux M, Amiot J, Boutin Y, Roy D. Immunomodulatory effects of probiotics in the intestinal tract. Curr Issues Mol Biol. (2008) 10:37.

45. Kaneko A, Matsumoto T, Matsubara Y, Sekiguchi K, Koseki J, Yakabe R, et al. Glucuronides of phytoestrogen flavonoid enhance macrophage function via conversion to aglycones by $\beta$-glucuronidase in macrophages. Immun Inflammation Dis. (2017) 5:265-79. doi: 10.1002/iid3.163

Conflict of Interest: The authors declare that the research was conducted in the absence of any commercial or financial relationships that could be construed as a potential conflict of interest.

Copyright (C) 2020 Al Obaydi, Hamed, Al Kury and Talib. This is an open-access article distributed under the terms of the Creative Commons Attribution License (CC $B Y)$. The use, distribution or reproduction in other forums is permitted, provided the original author(s) and the copyright owner(s) are credited and that the original publication in this journal is cited, in accordance with accepted academic practice. No use, distribution or reproduction is permitted which does not comply with these terms. 